\title{
INVERTED CONDYLOMA OF UTERINE CERVIX: A RARE CONDYLOMATOUS LESION
}

\author{
D. Prem Charles ${ }^{1}$, P. Narmadha², P. Viswanathan ${ }^{3}$, U. Manohar ${ }^{4}$
}

\begin{abstract}
HOW TO CITE THIS ARTICLE:
D. Prem Charles, P. Narmadha, P. Viswanathan, U. Manohar. "Inverted Condyloma of Uterine Cervix: A Rare Condylomatous Lesion". Journal of Evolution of Medical and Dental Sciences 2014; Vol. 3, Issue 54, October 20; Page: 12526-12530, DOI: 10.14260/jemds/2014/3660
\end{abstract}

\begin{abstract}
Human papillomavirus (HPV) is an epitheliotropic virus that can infect and cause disease of skin or mucosa at any site. HPV associated lesions can be broadly divided into cutaneous and mucous membrane lesions. Cutaneous lesions include: warts, Butcher's wart and epidermodysplasia verruciformis. The anogenital diseases, include warts (condyloma), dysplasia (cervical, vaginal, vulvar, anal), and squamous cell carcinoma. Here we are presenting a case report of a 27 year old female who was histologically diagnosed as inverted condyloma a rare condylomatous lesion involving the uterine cervix.
\end{abstract}

KEYWORDS: Inverted Condyloma, uterine cervix.

INTRODUCTION: Independent of the site or the type of lesion, the papilloma virus virion has a constant morphology and structure. ${ }^{1}$ The virion is a non-enveloped $8 \mathrm{~Kb}$ long icosahedral structure of 55-60 nm diameter, which forms paracrystalline arrays in the nucleus of infected cells. ${ }^{2}$

Epidemiologic studies show genital warts to be among the most common sexually transmitted diseases, after chlamydia and gonorrhea. The incidence of condyloma acuminatum has been steadily rising over the past three decades. ${ }^{3}$ W.H.O. estimates that 630 million people are infected with genital HPV, resulting in a worldwide prevalence of $9-13 \%{ }^{4}$

There is an inverse relationship between age and HPV prevalence in many countries. In some countries, cross-sectional and cohort studies have shown a U-shaped curve with a first peak in women under 30 years of age and a second peak in women aged 55-64 years.5It is believed that many sexually active adults are infected with HPV, but only $1 \pm 2 \%$ of them are found to have clinical lesions. Rest of the infections remain subclinical, with the latent HPV residing in the epithelial basal cells. ${ }^{6}$

The most important risk factor for genital warts are decreasing age of first sexual intercourse, multiple sexual partners and clinical history of other venereal diseases. ${ }^{7}$

CASE HISTORY: A twenty seven year old female presented with the complaints of leucorrhoea. On per-speculum unhealthy cervix was observed which was biopsied and sent for histopathological examination.

Microscopically, it shows nodules and nests of squamoid cells, occasional cells exhibiting Koilocytosis (FIG: 1) The cells are well differentiated with mild degree of pleomorphism (FIG: 2).

DISCUSSION: 'Condylomata' (figs) was the description given to genital warts as long ago as the Roman-Hellenistic era. ${ }^{8}$ During the past 10 years no fewer than 40 types and subtypes of HPV have been categorised and each appears to have a site of predilection which determines to a large extent the macroscopic characteristics and clinical behaviour of that particular wart type. 
Thus, for example, the deep plantar wart is associated with HPV type I, the common wart with type 2, epidermodysplasia verruciforrnis with types 3,14,15, 17 and $19-25$, and the small hyperkeratotic palmar and plantar warts with type 4.

The classification and morphological concepts of genital warts have also been revised since the description in 1976 and 1977 by Meisels and Fortin ${ }^{9}$ and Purola and Savia ${ }^{10}$ of not only a classic exophytic wart (condyloma acuminatum) but also a flat and an endophytic variety of wart affecting the uterine cervix.

Typing of the HPV virus associated with the above cervical lesions, using the techniques of DNA-DNA hybridisation with radiolabelled HPV probes, has implicated types 6, 11, 16, 18 and possibly 33. Types 16 and 18 in particular have been designated high-risk as regards malignant transformation. ${ }^{11,12}$

The majority of patients with genital HPV have no symptoms or physical findings. These are extremely important as they are invisible to the human eye. They may be observed by application of a solution of acetic acid followed by viewing using a magnifying glass or colposcope.

Productive papilloma virus infection are initiated when the virus enters proliferating basal epithelial cells, probably through micro wounds because this layer of cells is not normally accessible to the virus. ${ }^{13}$ However, viral particles and viral antigen are found mainly in the surface layer, indicating that the viral replication may be restricted to the differentiated cells in the epithelium. Replication of HPV in squamous epithelium is frequently associated with morphological changes in the cells; the most striking feature is koilocytic atypia. ${ }^{14}$

Cells showing this change are characterised by the presence of a large clear zone or halo which sorrounds the nucleus of the cell and displaces the cytoplasm to the periphery of the cell. The halo has a sharp border bounded by the thickened rim of cytoplasm. The nucleus of the koilocyte is usually enlarged, hyperchromatic and irregular in outline. The degree of nuclear abnormality may vary from slight enlargement and hyperchromasia to severe dyskaryosis. The presence of koilocytes in cervical biopsies and smear was considered to be the pathogonomic of Human papilloma virus infection.

\section{HPV infections of the cervix may result in development of four distinct Lesions:}

1. Exophytic warts or condyloma acuminate.

2. Non condylomatous wart virus infection or flat warts.

3. Spike or papillary condyloma.

4. Rare endophytic wart or inverted condyloma.

Until recently, exophytic Condylomata acuminate were regarded as the only manifestation of papillomavirus infection in the genital area. They occur on penis and vulva, in the perianal region, in the urethra, in the vagina, and at the uterine cervix. Histologically, they are characterized by papillomatosis, elongation and thickening of rete pigs, acanthosis, parakeratosis, and cytoplasmic vacuolization. ${ }^{15}$ The vast majority of exophytic condylomas appear to be induced by HPV 6 or $11^{16}$ and HPV 6 (65\%) seems to be prevalent than HPV 11(21\%).

Condylomata acuminata in vagina and cervix often reveal a flat growth pattern, which was previously diagnosed as mild dysplasia. They may not be visible to the naked eye but seen when magnified by colposcopy. The appearance of koilocytes in cervical smear was clearly indicative of papillomavirus infection, and the lesions are therefore currently referred to as flat condylomas. ${ }^{17}$ 
Some authors use alternative terms such as non condylomatous cervical wart virus infection or subclinical papilloma virus infection. ${ }^{18}$

The histology of flat condylomas shows acanthotic epithelium with mildly attenuated rete pegs, dyskeratosis, and koilocytotic atypia in superficial cells. In so called spiked or papillary condyloma, the blood vessels surrounded by scanty stroma push upward through the epithelium, giving rise to an uneven surface texture.

Inverted endophytic condyloma are basically identical to flat ones, but are characterized by pseudo invasive penetration in to underlying stroma.

The flat condyloma is the most common type in the cervix, representing about seventy percent of the cases, followed by papillary and inverted type. ${ }^{19}$

The present case was used to highlight Inverted condyloma due to viral infection can occur in the cervix which had the potential to become invasive malignant tumor at some point of time. Hence long term follow up is recommended.

\section{REFERENCES:}

1. Baker TS, Newcomb WW, Olson NH, et al. Structures of bovine and human papillomaviruses. Analysis by cryoelectron microscopy and three-dimensional image reconstruction. Biophys J 1991; 60: 1445-1456.

2. Howley PM, Lowy DR. Papillomaviruses and their replication, Chapter 65. In: Field's Virology, Volume 2, 4th ed. Knipe DM, Howley PM, editors. Lippincott Williams and Wilkins: Philadelphia 2001 p. 2197-229.

3. Center for Disease Control (CDC). Condyloma acuminatum D United States, 1966 \pm 1981 . Morbidity and Mortality Weekly Report 1983; 32: 306 \pm 308 .

4. Forcier M, Musacchio N. An overview of human papillomavirus infection for the dermatologist: disease, diagnosis, management, and prevention. Dermatologic Therapy 2010; 23: 458-476.

5. Munoz N, Mendez F, Posso H, et al. Incidence, duration, and determinants of cervical human papilloma virus infection in a cohort of Colombian women with normal cytological results. J Infect Dis 2004; 190: 2077-87.

6. Wiley DJ, Douglas JM, Beutner K, et al. External genital warts: diagnosis, treatment, and prevention. Clin Infect Dis 2002: 35 (Suppl. 2): S210-S224.

7. La Vecchia C, Franceschi S, Decarli A, et al. Sexual factors, venereal diseases and the risk of intraepithelial and invasive cervical neoplasia. Cancer1986; 58: 935- 41.

8. Orrho G, Jablonska S, Breitbund F el al. The human papillomaviruses. Bull Cancer 1978; 65: 151.

9. Meisels A, Fortin R. Condylomatous lesions of me cervix and vagina: cytological parrems. A Cla CYLOI (BalLimore) 1976; 20: 505.

10. Purola E, Savia E. Cytology of gynecological condylomata acuminata. Acta Cytol (Baltimore) 1977; 21: 26.

11. Gissman L, Walnik L, Ikenberg H er al. Human papilloma types 6 and I, DNA sequences in genital and laryngeal papillomas and in some cervical cancers. Proc Nacl Acad Sci USA 1983; 80: 560563.

12. Durst M, Gissman L, Ikenberg H et al. A papilloma-virus DNA from a cervical carcinoma and its prevalence in cancer biopsy specimens from different geographic regions. Proc Nail Acad Sci USA 1983; 80: 3812-3815. 
13. Doorbar J. The papilloma virus life cycle. J Clin Virol 2005; 32 (suppl 1): S 7-15.

14. Koss LG, Durfee GR. Unusual pattern of squamous epithelium of the uterine cervix; cytologic and pathologic study of koilocytic atypia. Ann NY Acad Sci 1956; 63; 1245-1261.

15. Woodruff JD, Peterson WF. Condyloma acuminata of the cervix. Am J Obstet Gynecol. 1958 Jun; 75(6): 1354-1362.

16. Gissmann L, Wolnik L, Ikenberg, H, Koldovsky U, Schnurch HG, Zur Hausen H. Human papilloma Virus types 6 and 11 DNA sequences in genital and laryngeal papillomas and in some cervical cancers. Proc Natl Acad Sci USA. 1983 Jan; 80(2):560-563.

17. Purola E, Savia E. Cytology of gynecologic condyloma acuminatum. Acta cytol; 1977; 21:26-31.

18. Reid R, Stanhope CR, Herschman BR, Booth E, Phibbs GD, Smith JP. Genital warts and cervical cancer.I. Evidence of an association between subclinical papilloma virus infection and cervical malignancy. Cancer.1982 Jul 15: 50(2): 377-387.

19. Meisels A, Fortin R, Roy M. Condylomatous lesions of the cervix. II. Cytologic, colposcopic and histopathologic study. Acta Cytol. 1977 May-Jun; 21(3):379-390. [PubMed]

\section{MICROSCOPIC PICTURES: H \& E SECTIONS}

FIG 1: NODULES OF SQUAMOID CELLS EXHIBITING KOILOCYTIC CHANGES:
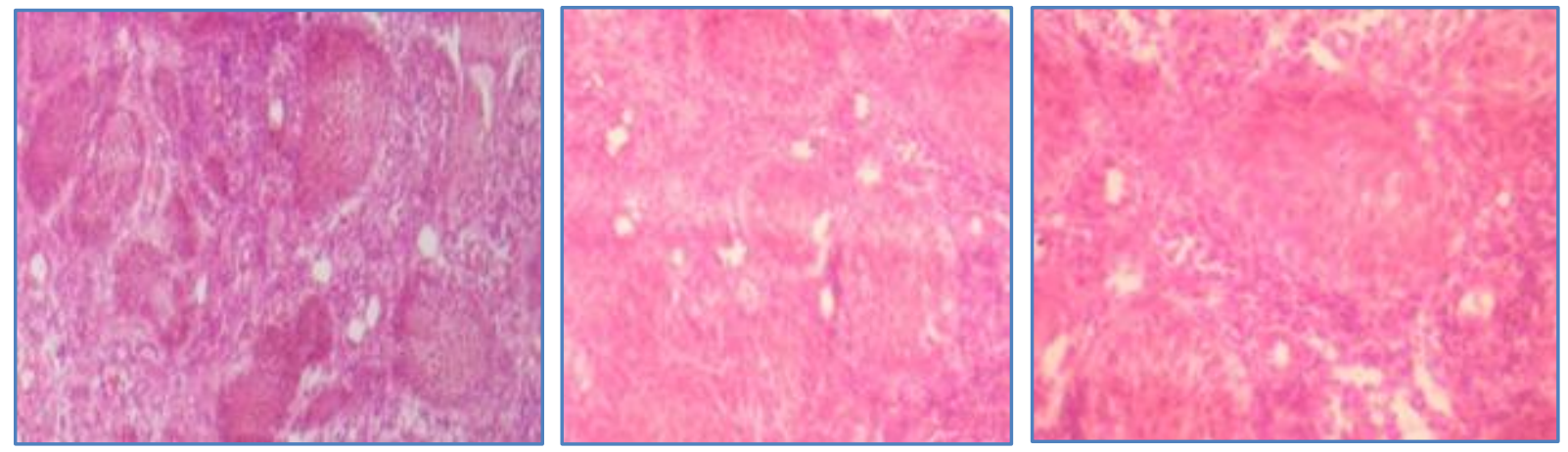

FIG 1: 4X, 10X, 40X

FIG 2: NESTS OF SQUAMOID CELLS WHICH ARE WELL DIFFERENTIATED EXHIBITING KOILOCYTOSIS AND MILD DEGREE OF DYSPLASIA
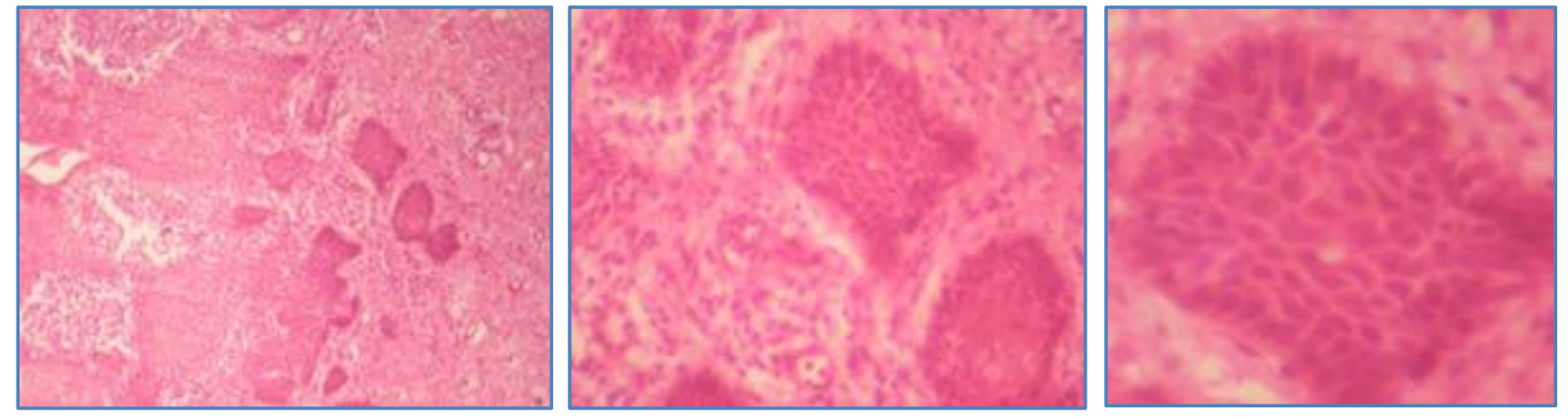

FIG 2 


\section{AUTHORS:}

1. D. Prem Charles

2. P. Narmadha

3. P. Viswanathan

4. U. Manohar

\section{PARTICULARS OF CONTRIBUTORS:}

1. $3^{\text {rd }}$ Year Post Graduate, Department of Pathology, Rajah Muthiah Medical College, Annamalai University.

2. $3^{\text {rd }}$ Year Post Graduate, Department of Pathology, Rajah Muthiah Medical College, Annamalai University.

3. Professor and HOD, Department of Pathology, Rajah Muthiah Medical College, Annamalai University.

4. Professor, Department of Pathology, Rajah Muthiah Medical College, Annamalai University.

\section{NAME ADDRESS EMAIL ID OF THE} CORRESPONDING AUTHOR:

Dr. P. Viswanathan,

Professor and HOD,

Department of Pathology,

Faculty of Medicine,

Rajah Muthiah Medical College,

Annamalai University,

Chidambaram-608002,

Tamilnadu, India.

Email: drpviswanathan2013@gmail.com

Date of Submission: 06/10/2014.

Date of Peer Review: 07/10/2014.

Date of Acceptance: 15/10/2014.

Date of Publishing: 20/10/2014. 